\title{
Economic Evaluation of Production Costs and Returns of Potato Crop in Sylhet Region of Bangladesh
}

\author{
Md. Shah Alamgir'1, Md. Rashid Ahmed1, Jasim Uddin Ahmed'2, Rubaiya Binte Mostafiz ${ }^{3}$ \\ ${ }^{1}$ Department of Agricultural Finance and Banking, Sylhet Agricultural University, Sylhet, Bangladesh \\ ${ }^{2}$ Department of Agricultural Economics and Policy, Sylhet Agricultural University, Sylhet, Bangladesh \\ ${ }^{3}$ Graduate School of Life and Environmental Sciences, University of Tsukuba, Ibaraki, Japan \\ Email: salamgir.afb@sau.ac.bd
}

How to cite this paper: Alamgir, Md.S., Ahmed, Md.R., Ahmed, J.U. and Mostafiz, R.B. (2020) Economic Evaluation of Production Costs and Returns of Potato Crop in Sylhet Region of Bangladesh. Natural Resources, 11, 96-111.

https://doi.org/10.4236/nr.2020.113006

Received: January 6, 2020

Accepted: March 17, 2020

Published: March 20, 2020

Copyright (๑) 2020 by author(s) and Scientific Research Publishing Inc. This work is licensed under the Creative Commons Attribution International License (CC BY 4.0).

http://creativecommons.org/licenses/by/4.0/

\begin{abstract}
Potato production is becoming one of the major profitable crops among the famers in the northeastern part of Bangladesh. This study investigates the occupational status, land tenure arrangement, household income scenarios, and estimates the level of costs and net income variation for potato production in the greater Sylhet areas of Bangladesh by using the both descriptive and statistical techniques. The descriptive results exhibit that most of the households involved in farming as well as other income generating activities; however, the highest income share comes from the household business followed by agricultural activities. Near about half of the farmers belonged from the small category ( 46.39 percent) and around 37 percent were pure tenant while 30 percent were mixed tenant involved with both sharecropping and cash lease farming. Nonagricultural income and remittance are the key income sources of employment that influence the average per capita income. Agriculture share was approximately 9 percent in total household income where rice dominates the major share and potato does not have significant contribution. However, seed, irrigation, fertilizer, and hired labor cost were the major cost components for potato cultivation. This study also decomposed the variance of net income into different factors and found that gross income difference exists among the farmers due to the fertilizer and seed cost variation. Gross income explained the net income variation, which implies that potato yield or potato price (quality) or both vary widely among the farmers. This study can contribute to making links between the shares of farm household income that would be helpful for policy makers to understand the causes of cost and income variation as well as opt for better strategies to support the farmers.
\end{abstract}




\section{Keywords}

Cost, Net Income, and Potato Production

\section{Introduction}

In terms of human consumption potato is the third most important food crop in the world [1]. Potato is not only cash crop for farmers but also many countries including one billion people consume as a staple food as like as rice and more than 100 countries grown as food crops. The potato is not an outstanding source of energy yet a good source of high-quality protein, major source of vitamin C and it is rich in important minerals [2]. To reduce the rice consumption, potato is the best alternative, which provides same nutrition that is why potato consumption is increasing in developing countries. Due to the demand of potato, production area has also rapidly increased and overtaken all other food crops in developing countries. Presently, the developing countries for food security of millions of people supply major portion of global potato across South America, Africa, and Asia [1].

Farmers of Bangladesh have been producing potato as a major food and cash crop to earn more profit rather than rice cultivation, though in recent years, potato production reduced drastically as result of unscrupulous weather condition due to changing climate. People of Bangladesh mainly used potato as vegetable and nowadays it has been changing to the main dish on the dining table. In some previous years farmers also faced price fluctuation in harvesting season and received a low price when bumper production [3].

The rapid increase in population creates the additional demand for vegetables specially potato in Sylhet of Bangladesh. However, the supply of vegetables is inadequate for meeting up the demand of current people living in Sylhet region. Agriculture is the key source of income (51.34\% of total income), though in last two decades, the cropping intensity of Sylhet region is almost stagnant [3] [4] [5] [6]. In these circumstances, the appropriate cropping pattern is necessary for Sylhet region where farmers are producing different crops including potato as major crops in rural areas. For sustainable farm production, diversified cropping pattern is a good choice for the farmers [7].

Sylhet region is a potential area for agricultural production [8] across the haor area laying below the northeastern Himalayan foothills experience the highest rainfall in the world to make the basin prone to flashflood. Despite the potentiality of agricultural production in Sylhet region, potato crop is easy to achieve the farming practice. However, farm income link with potato production and its prospects, costs, and returns of potato crop research are very few on this area. Hence, the study designed to assess the socio-economic and demographic attributes of farm households and determine the level of costs and net income variation for potato production in Sylhet region of Bangladesh. Therefore, this 
study can help the policy makers to take decision for the improvement of potato farming as well as diversified agricultural practices by the farmers in rural areas of Bangladesh.

After a brief overview of the importance of potato production followed by Sylhet region, we draw a review of potato production and trend in Bangladesh with the focus on the problems in Section 2. Section 3 is the methodology section, where we describe the sources of data and analytical procedures; in Section 4, we presented the results of the analysis with discussion; and in Section 5, we conclude the results by emphasizing the limitations and future research with some policy options.

\section{Problem Statement}

Potato is an effective food crop and it can play an important role in the food security of Bangladesh [9]. Production and export of potato has a great prospect in Bangladesh [10] and it ranks 11th in the world in terms of potato production in 2008 [11], and according to FAOSTAT, 2013 [12] it was seventh position in the world (Figure 1). In Bangladesh, potato is consumed as an important winter vegetable and is widely produced in the whole country. Considering the production area potato is the third major crop in Bangladesh.

According to the BBS report 2015 [5], the area and production of potato gradually increased in Bangladesh after the year 2000, although in the year 2008-09, the production was decreased due to severe flooding in whole country (Figure 2). However, after that year, the production of the potato goes to the increasing trend and recently it is nearly 10 million metric tons. Specifically, some regions are well known for potato production such a Munshiganj, Rangpur, Bogra, Comilla, Dinajpur, Joypurhat, and Nilphamari [6].

Besides these areas at present the farmers in northeastern part of Bangladesh (Sylhet, Sunamganj, Habiganj, and Moulvibazar) are cultivating potato as important rabi crops including boro rice, sweet potato, mustard, lentil and, other winter vegetables [6]. Some previous study results show that farmers can earn

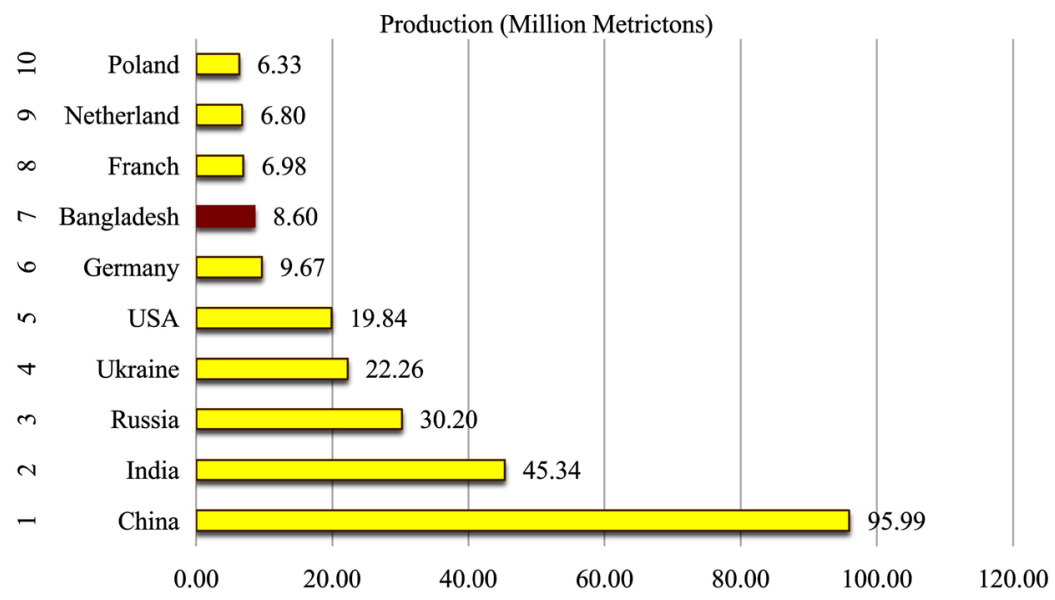

Figure 1. World potato production [12]. 


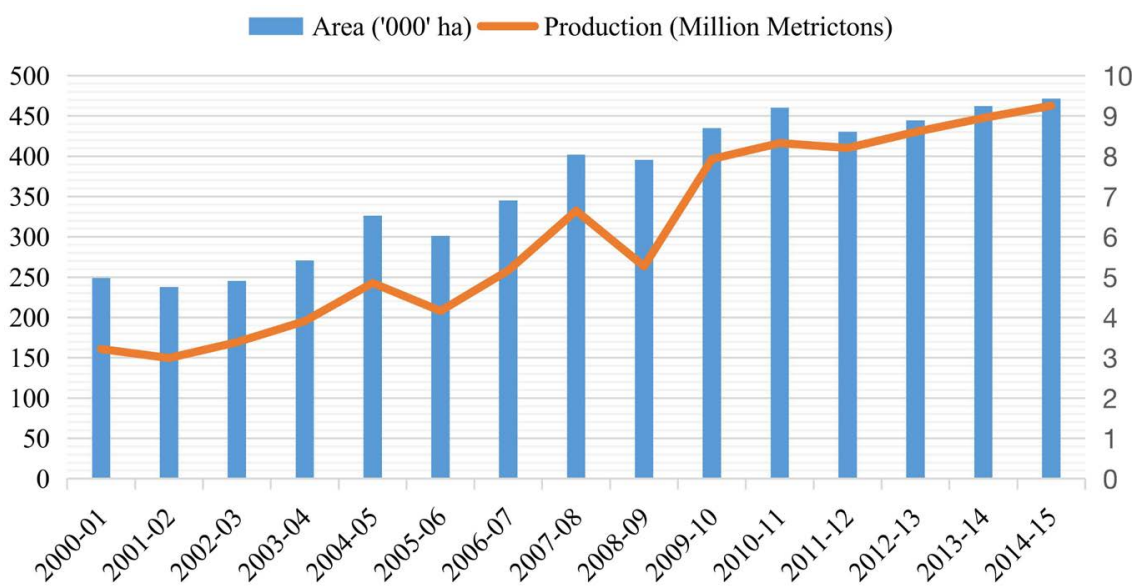

Figure 2. Trend of potato production in Bangladesh [5].

very high financial and economic return through potato production and mentioned that highest yield of potato was 28 tons per hectare found in Rangpur region followed by Thakurghaon region ( 25.6 ton/ha) and Comilla region (24.5 ton/ha) [13]. The gross return and gross margin of potato cultivation in Rangpur district were BDT211978 and BDT139388 per hectare, respectively whereas the average gross margin and BCR for potato cultivation were BDT174319/ha and 2.40, respectively in Munshiganj, Bogra and Jessore [14]. The average net profit of potato production per acre in these districts was BDT12731 but the medium farmers cultivate more land; however, the net profit was highest for large farmers [15]. On an average, per hectare, cost of production for potato in Sylhet district was BDT194114 and the average per hectare yield of potato was 17194 $\mathrm{Kg}$ [16]. However, the cost of production was higher, while the price of potato was lower at the time of harvest and consequently, farmers became looser in the northern part of the country [17].

Sylhet is a complex region for agricultural production due to its variable landscape ranged from hills to very lowlands with the diverse microenvironment [8] [18]. Sylhet region comprises with the four districts with total area $12298.4 \mathrm{sq}$ $\mathrm{km}$, located in between $23^{\circ} 58^{\prime}$ and $25^{\circ} 12^{\prime}$ north latitudes and in between $90^{\circ} 56^{\prime}$ and $92^{\circ} 30^{\prime}$ east longitudes. This region is bounded by Meghalaya state of India on the north, Tripura state of India on the south, Assam state of India on the east, Netrokona, and Kishoreganj districts on the west [6]. Due to the capricious topography of Sylhet region, agricultural production is very critical; however, farmers continue to grow different crops in different seasons. In majority of the areas are cultivating rice by farmers in this region and supports the total farm income of households. In addition, others crop such as potato, vegetables etc. have the potential in Sylhet region because of the financial return is more than any other crops. Despite the potentiality of potato in Sylhet region, the production trend, and practice is not reasonable level [19]. To address this need, the prospects of potato production by emphasizing the farm income of household in Sylhet region if necessary. 
It is very important to understand the cost and returns of potato cultivation in Sylhet region and to take the decision for best alternative crops for production. Unfortunately, most of the previous studies examining the costs and returns of major agricultural crop such as rice, wheat etc. in Sylhet region. However, detailed studies on farm income, share of agricultural income with the emphasis on potato crop, and its prospects in Sylhet region is very scanty. This article seeks to determine the occupational status, land tenure arrangement, household income scenarios, and estimates the level of costs and net income variation for potato production in the Sylhet region of Bangladesh.

\section{Methodology}

This study used the cross-sectional farm household survey data, collected by the International Food Policy Research Institute (IFPRI) in 2011-2012 year by randomly drawn households and direct interview with structured questionnaires. This survey was the first integrated farm household survey 2012 in Bangladesh. For this study, the secondary data collected from the IFPRI website [20], and arranged according to the set objectives for the Sylhet region of Bangladesh (Figure 3). In Sylhet region, there are four districts where 36 villages including 20 -farm households from each village and total 720 -farm households selected randomly for primary data collection by IFPRI. We edited, summarized, tabulated, and analyzed the collected raw data from IFPRI to fulfill the objectives of this study. Descriptive statistics, variance, and covariance analysis mostly used in this study. From the 720 farm households we separated potato growing households and found only 48 farm households cultivated potato where 13 farm households in Habiganj, 30 in Moulobibazar, 2 in Sunamganj and 3 in Sylhet district. In socioeconomic part of the study, we checked the all-720 farm household data; and for cost and income of potato production, we used 48 sample households those are cultivated potato. To grasp the diversity of income, we decompose the variance in net income of potato production into different factors using the following relations, which are well known.

$$
V(M \pm N)=V(M)+V(N) \pm 2 \operatorname{cov}(M, N)
$$

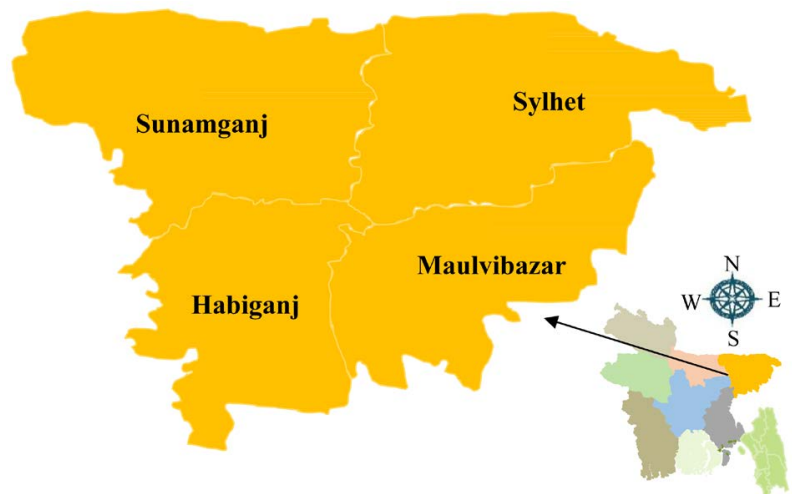

Figure 3. Map of the study areas (Sylhet region) in Bangladesh. 
where, $M$ and $Y$ are stochastic variables, such as the costs of inputs or incomes from different sectors; $\mathrm{V}$ is variance and Cov is covariance.

\section{Results and Discussions}

\subsection{Descriptive Statistics of Sampled Farm Households}

Table 1 exhibits the basic statistics of farm households. The study found that household size is moderately higher than the national average (4.8) [5]. An important and interesting finding of the study is that almost one-fifth of farm households were controlled by the female, which is really an encouraging situation for farming households, as their involvement in decision-making. Majority (56.7\%) of the people aged 15 years and over was literate, while $53.3 \%$ were women. In most of the villages of Bangladesh, women's access to education is increasing considerably and changing their living status by doing small jobs, petty business, and becoming entrepreneurs over the years.

Occupation is the most important feature for a household to sustain in the earth. Household income fully depends on better occupation, and income is the basic requirements for improved household food security. Figure 4 provides the percentage of household head and their involvement in different income earning activities. At the root label of the Sylhet region, most of the people involved in farming, accounted for nearly $43 \%$ followed by business/trade, daily labor and other income generating activities. Bangladesh is predominantly an agrarian society where most of the farm household participated in farming that made commendable progress in food production [20]. However, income share from farming in total household income is not so significant. Because, service sector represents the main source of household income in Bangladesh [21].

\subsection{Distribution of Land and Tenure Arrangement of Sampled Farm Households in Sylhet Region}

According to the reference of Bangladesh Bureau of Statistics, the sample farmers categorized in four-farm size groups [3]. The marginal farmer belongs whom operating lower than the 0.20 hectares of land, small farmers 0.20 to 0.60

Table 1. Summary statistics for the sampled farms.

\begin{tabular}{cc}
\hline Household characteristics & Household data \\
Household size & 5.9 persons \\
Average landholding size (owned cultivable) & 0.302 ha \\
Female headed household & $19.0 \%$ \\
Literacy rate for people aged 15 years and over \\
Male \\
Female \\
All \\
.
\end{tabular}




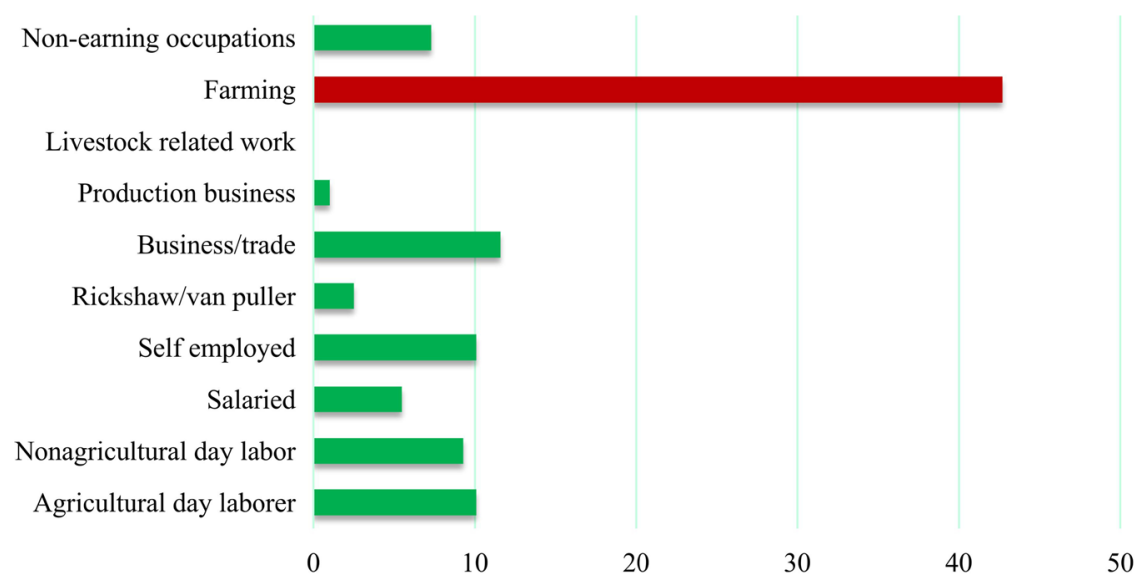

Figure 4. Principal occupations of household head.

hectares of land, medium farmers who have the 0.60 to 1 hectare of land, and large farmers who has more than 1 hectare of land. Figure 5 represents the percentage of farmers operating the different size of farming land in the study areas. The highest proportion of farmers belonged to the small farmers group accounted for $46.39 \%$ which means that in Sylhet region a small percentage of farm household has the large farming land and the similar pattern are exist in overall rural areas of Bangladesh [20]. Another significant finding is that the lowest percentage of farmers was marginal.

Land tenure pattern is a common scenario in farming all over the world. In Bangladesh, the farmers are following different types of land tenure arrangements: pure tenant, mixed tenant, and farmers own cultivated land. In pure tenant and mixed tenant, farmers are following the sharecropping, cash lease, and both. The leading tenure arrangement is following by the farmers in Bangladesh are sharecropping where the production is shared by the landowner and cultivator in different proportions that are fixed before the cultivation. Figure 6 illustrates the different land tenure arrangements in rural areas of Sylhet region in Bangladesh. The highest portion of farmers was pure tenant (36.8\%) which implies that a large portion of farmers has no own land for farming, and they operate other lands under the sharecropping or lease arrangement. Meanwhile, under pure tenant situation, near about $73 \%$ of farmers followed the sharecropping whereas it was almost $60 \%$ under mixed tenant. A minority of farmers followed cash lease and a noticeable portion of them involved in both sharecropping and cash lease.

\subsection{Income Share of Sampled Farm Households in Sylhet Region}

This section illustrates the income sources of households and percentage share in each source by districts in Sylhet region. From Table 2 we found that employment is key source of household income that followed non-agriculture, remittance and agriculture income. Here in Agricultural income, we separated key crops such as aus, aman and boro rice; and supplementary crops such as wheat, 


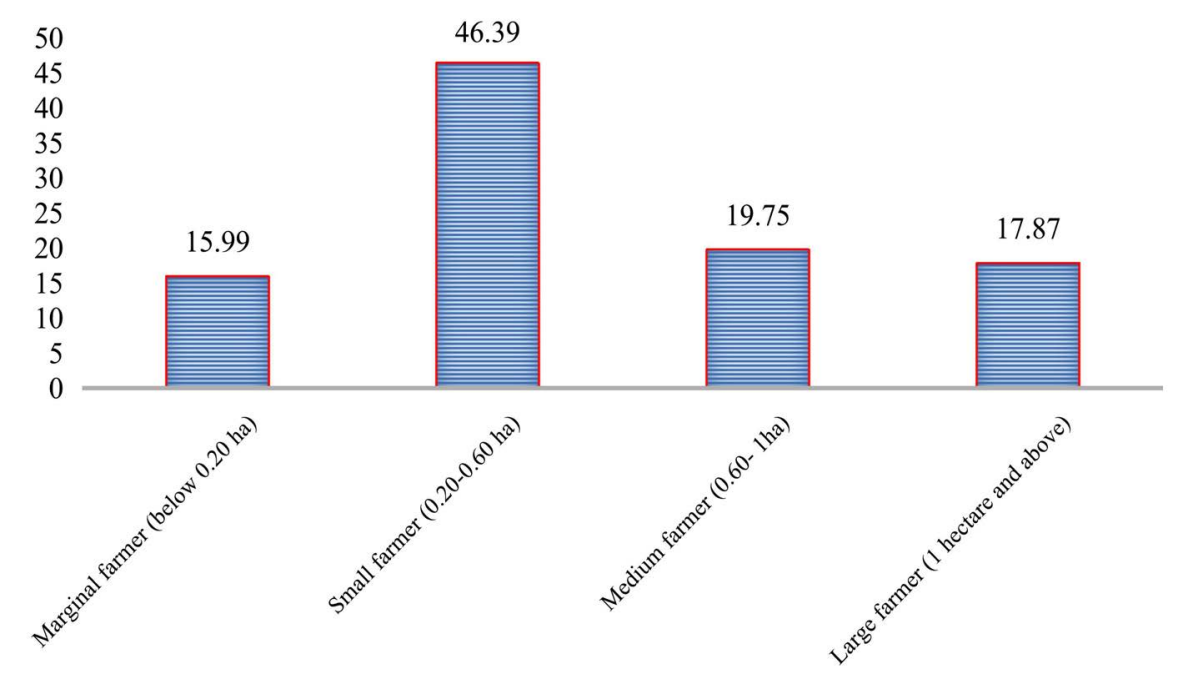

Figure 5. Distribution of operated land by farm size groups.

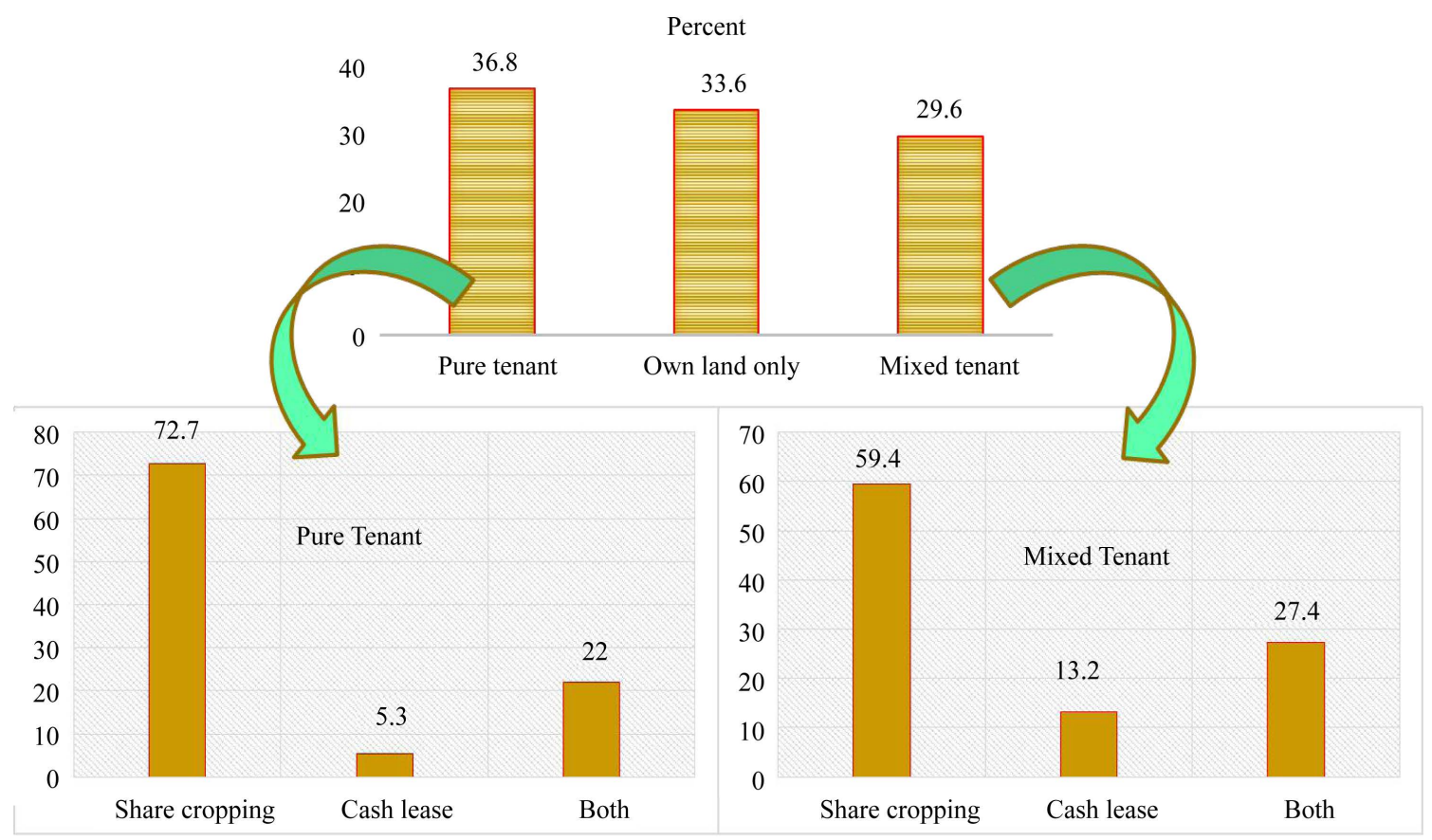

Figure 6. Land tenure arrangements in Sylhet region.

maize, jute, potato, chili, onion and so on. In Table 3, we discussed the agricultural income and individual crops. Sylhet is particularly acquainted for remittance income and it is very common in this region that many people are living abroad and send remittance for their family [21]. Table 2 presents the significant share of total household income comes from remittance and highest in Sylhet district. Fish and livestock income are lowest share in total household income except in Sunamganj since fish is important sources for income. The study region specially, Sunamganj and Habiganj is eminent with haors as well as sweet water fish [6]. 
Md. S. Alamgir et al.

Table 2. Average and percentage of income (BDT) sources share by districts in Sylhet region.

\begin{tabular}{|c|c|c|c|c|c|}
\hline & Habiganj & Moulobibazar & Sunamganj & Sylhet & Total region \\
\hline Agriculture & $\begin{array}{l}14486 \\
(9.89)\end{array}$ & $\begin{array}{c}10331 \\
(13.13)\end{array}$ & $\begin{array}{c}12679 \\
(11.69)\end{array}$ & $\begin{array}{c}6659 \\
(4.60)\end{array}$ & $\begin{array}{l}11111 \\
(9.16)\end{array}$ \\
\hline Key crops & $\begin{array}{c}8542 \\
(5.83)\end{array}$ & $\begin{array}{c}7901 \\
(10.18)\end{array}$ & $\begin{array}{c}9495 \\
(8.75)\end{array}$ & $\begin{array}{c}4295 \\
(2.97)\end{array}$ & $\begin{array}{c}7632 \\
(6.29)\end{array}$ \\
\hline Supplementary crops & $\begin{array}{c}5944 \\
(4.06)\end{array}$ & $\begin{array}{c}2430 \\
(3.13)\end{array}$ & $\begin{array}{c}3184 \\
(2.93)\end{array}$ & $\begin{array}{c}2364 \\
(1.63)\end{array}$ & $\begin{array}{c}3479 \\
(2.87)\end{array}$ \\
\hline Fish & $\begin{array}{c}4552 \\
(3.11)\end{array}$ & $\begin{array}{c}423 \\
(0.54)\end{array}$ & $\begin{array}{c}8886 \\
(8.19)\end{array}$ & $\begin{array}{c}1364 \\
(0.94)\end{array}$ & $\begin{array}{c}3832 \\
(3.16)\end{array}$ \\
\hline Livestock & $\begin{array}{c}3546 \\
(2.42)\end{array}$ & $\begin{array}{c}1678 \\
(2.16)\end{array}$ & $\begin{array}{c}2855 \\
(2.63)\end{array}$ & $\begin{array}{c}727 \\
(0.50)\end{array}$ & $\begin{array}{c}2175 \\
(1.79)\end{array}$ \\
\hline Non-agriculture & $\begin{array}{c}38512 \\
(26.31)\end{array}$ & $\begin{array}{c}6648 \\
(8.56)\end{array}$ & $\begin{array}{c}23823 \\
(21.96)\end{array}$ & $\begin{array}{c}26039 \\
(17.99)\end{array}$ & $\begin{array}{c}24294 \\
(20.02)\end{array}$ \\
\hline Remittance in & $\begin{array}{l}11637 \\
(7.95)\end{array}$ & $\begin{array}{c}15732 \\
(20.26)\end{array}$ & $\begin{array}{c}18951 \\
(17.47)\end{array}$ & $\begin{array}{c}37425 \\
(25.86)\end{array}$ & $\begin{array}{c}21539 \\
(17.75)\end{array}$ \\
\hline Employment & $\begin{array}{c}62365 \\
(42.60)\end{array}$ & $\begin{array}{c}41519 \\
(53.47)\end{array}$ & $\begin{array}{c}40034 \\
(36.90)\end{array}$ & $\begin{array}{c}66630 \\
(46.05)\end{array}$ & $\begin{array}{c}53335 \\
(43.95)\end{array}$ \\
\hline Other income & $\begin{array}{l}11302 \\
(7.72)\end{array}$ & $\begin{array}{c}1313 \\
(1.69)\end{array}$ & $\begin{array}{c}1270 \\
(1.17)\end{array}$ & $\begin{array}{c}5857 \\
(4.05)\end{array}$ & $\begin{array}{c}5061 \\
(4.17)\end{array}$ \\
\hline Total income & $\begin{array}{c}146400 \\
(100)\end{array}$ & $\begin{array}{c}77643 \\
(100)\end{array}$ & $\begin{array}{c}108498 \\
(100)\end{array}$ & $\begin{array}{c}144701 \\
(100)\end{array}$ & $\begin{array}{c}121348 \\
(100)\end{array}$ \\
\hline Percapita & 31593 & 15893 & 22137 & 29055 & 25064 \\
\hline
\end{tabular}

Table 3. Percentage of crops income share by districts in Sylhet region.

\begin{tabular}{|c|c|c|c|c|c|}
\hline & Habiganj & Moulobibazar & Sunamganj & Sylhet & Total region \\
\hline Rice & 57.68 & 74.21 & 74.26 & 64.07 & 67.05 \\
\hline Aus & 4.37 & 12.28 & 1.13 & 5.15 & 5.19 \\
\hline Aman & 14.93 & 34.24 & 10.81 & 19.21 & 18.45 \\
\hline Boro & 38.38 & 27.68 & 62.32 & 39.72 & 43.41 \\
\hline Wheat & 0.00 & 0.00 & 0.00 & 0.00 & 0.00 \\
\hline Maize & 0.00 & 0.00 & 0.00 & 0.00 & 0.00 \\
\hline Jute & 0.06 & 0.00 & 0.30 & 0.00 & 0.11 \\
\hline Potato & 1.35 & 2.30 & 0.00 & 0.47 & 1.00 \\
\hline Chili & 0.48 & 0.05 & 1.00 & 0.39 & 0.53 \\
\hline Onion & 0.01 & 0.00 & 0.00 & 0.00 & 0.00 \\
\hline Other crops & 40.43 & 23.44 & 24.43 & 35.07 & 31.31 \\
\hline Total & 100 & 100 & 100 & 100 & 100 \\
\hline
\end{tabular}


Table 3 shows the shares in percentage of individual crops in total agricultural income by districts. Rice is the dominant crop in all districts where boro rice variety lead the major share. However, other crops have also the remarkable contribution in total agricultural income of household. Other crops included all types of crops, vegetables, pulses, and fruits produced by the farmers and not separately mentioned in the Table 3 . In major crops, potato is an important crop in Bangladesh [19] since the share is very small in the study areas. Due to the topographical location and soil condition of the study areas potato is not familiar crop in Sylhet region. Sylhet is a unique and almost rice monoculture-cropping areas [20] and considerable part is under tea plantation for hilly topography. However, farmers are growing this crop simultaneously with other crops and production is increasing.

From the above results, we found that agriculture is a key source of household income in Sylhet region, and cereal crops lead the highest share similar to other areas of Bangladesh. Potato has very small share in total household income since highest in Moulobibazar 2.30 percent of total agricultural income. This is the important research question why potato share is very low in total agricultural income of this region. The next section estimates the costs of production and returns for potato cultivation by farmers of Sylhet region.

\subsection{Costs and Returns of Potato Crop Cultivated by the Sampled Farms}

This section mainly focused on potato production and its relevant costs consideration as well as returns from potato cultivation in Sylhet region. Figure 7 presents the per hectare average costs of potato production in the Sylhet region which delineates that seed cost is the main input cost of potato production, followed by irrigation and hired labor cost for farmers. Generally, potato production depends on sowing seed, but the cost of potato seed is higher. It is revealed that around half of the input costs for potato production were expensed for seed purchasing.

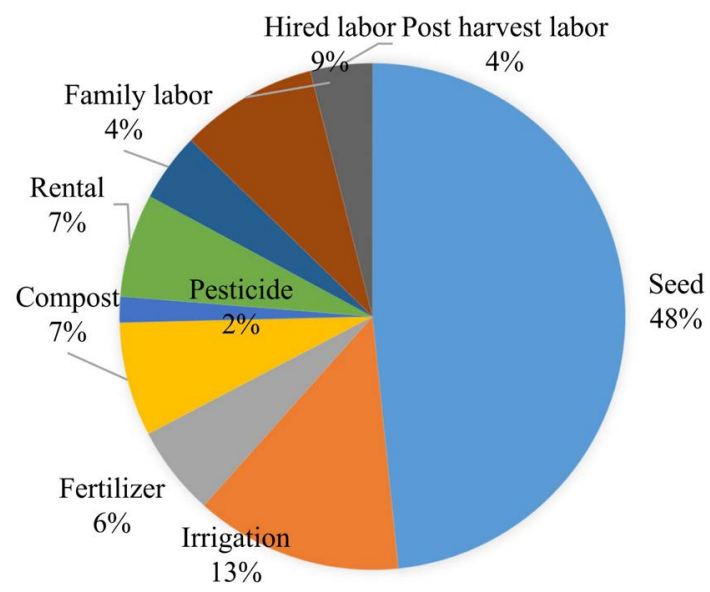

Figure 7. Average cost share for potato production. 
Table 4 presents a clear scenario for costs and output of potato cultivation in the study area. The study found that per hectare total cost was about BDT 37283.51 and sale price from the produced potato $(7801 \mathrm{Kg} / \mathrm{ha})$ was BDT 65443.5. It means potato is a profitable crop for farmers as they earn a considerable amount of return from its production after the reduction of costs. Most of the potato farmers in Bangladesh use their own collection of seed and traditional irrigation techniques.

Although potato cultivation is profitable, most of the farmers are producing rice as the main production crop followed by potato. One important reason behind the farmers' priority on rice production rather than other crops is that they want to ensure their daily's required food intake because rice is the staple food in Bangladesh and has relatively provide more calories which is essential for their food security. Each farm household used a small portion of their land for potato cultivation and it is depending on the location of land. Normally low and wetland is not suitable for potato production but in the Sylhet region, most of the areas are low land and in the rainy season, most of the cultivated areas affected by flood in every year [19]. Consequently, the average area of potato production in this region is very low, though; potato is the probable best alternative crop for farmers in the Sylhet region if they use high land for potato production rather than rice. From the Table 4, we found that seed and irrigation is the most important cost for potato cultivation, and farmers are used fertilizer, compost, pesticide, irrigation etc. for maximum yield. These costs variables have close relation that can affect each other and consequently in potato yield. The next section we check the correlation between costs of potato production.

Table 4. Production costs (BDT/ha) for potato in Sylhet region.

\begin{tabular}{cc}
\hline Items & Production cost (BDT/ha) \\
Seed & 18033.3 \\
Irrigation & 4932.6 \\
Fertilizer & 2139.3 \\
Compost & 2713.0 \\
Pesticide & 616.3 \\
Rental & 2460.5 \\
Family labor & 1635.78 \\
Hired labor & 3278.4 \\
Post-harvest labor & 1474.2 \\
Animal and machinery & 0 \\
Total Cost & 37283.51 \\
Total output (Kg/ha) & 7801.4 \\
Total sale price & 65443.5 \\
\hline
\end{tabular}


Table 5 represents the correlation results of costs for potato production, and it is documented that some of the pairwise variable has shown significant correlation between the variables, remarkably for fertilizer and pesticide; compost and pesticide. This dual relationship between the variables would affect each other's [22]. In this analysis, bivariate correlation (no controlling variables) is used and in Figure 8, shows that some explanatory variables suspect to have close relationship with significant correlation, notable in pesticide and compost; and pesticide and fertilizer.

From Table 4, we found that some cost share has the significant roles to increase the total cost for potato production and where seed and irrigation was highest. Now, we want to check the disparity of costs that induced the variation of total cost. Based on correlation check, we suppose that there is a significant correlation between compost and chemical fertilizer, pesticide and chemical fertilizer, and pesticide with compost. Table 6 presents the results of variation of total cost disparity and show the factors responsible for large variations in cost from potato production.

Table 5. Correlation between costs of potato production.

\begin{tabular}{|c|c|c|c|c|c|c|c|c|}
\hline Variable & SE & IRR & $\mathrm{FE}$ & $\mathrm{CO}$ & PE & $\mathrm{RE}$ & HL & PHL \\
\hline Seed & 1 & & & & & & & \\
\hline Irrigation & 0.079 & 1 & & & & & & \\
\hline Fertilizer & 0.207 & 0.135 & 1 & & & & & \\
\hline Compost & 0.006 & 0.118 & 0.542 & 1 & & & & \\
\hline Pesticide & 0.060 & 0.077 & 0.771 & 0.877 & 1 & & & \\
\hline Rental & 0.277 & 0.085 & 0.647 & 0.406 & 0.416 & 1 & & \\
\hline Hired labor & 0.227 & 0.223 & 0.455 & 0.017 & 0.097 & 0.320 & 1 & \\
\hline Post-harvest labor & -0.105 & 0.320 & -0.176 & -0.115 & -0.141 & -0.144 & 0.00 & 1 \\
\hline
\end{tabular}

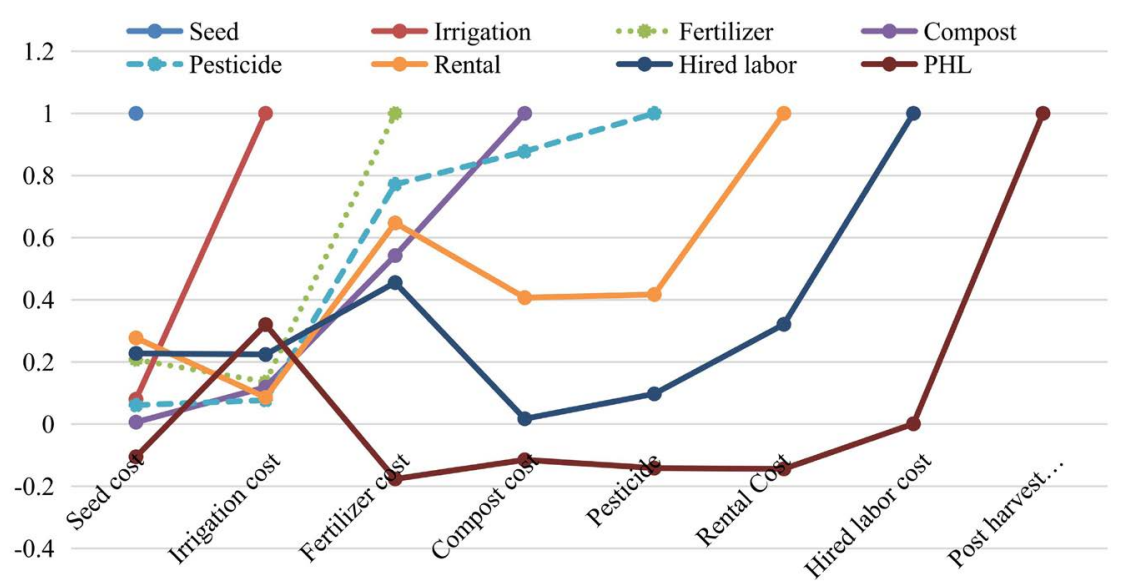

Figure 8. Correlation between costs of potato production. 
Table 6. Total cost disparity of potato production.

\begin{tabular}{ccc}
\hline Variables (cost items) & Covariance value of costs & Share (\%) of total \\
\hline Seed & 134065711 & 28.5 \\
Irrigation & 36482306 & 7.8 \\
Fertilizer & 19261865.1 & 4.1 \\
Compost & 49182443.9 & 10.5 \\
Pesticide & 2160887.03 & 0.45 \\
Rental & 35349774.9 & 7.52 \\
Hired labor & 82387453.5 & 17.52 \\
Post-harvest labor & 15918429 & 3.38 \\
$2^{*}$ co(PECO) & 18085780.7 & 3.84 \\
$2^{*}$ co(PEFE) & 9952995.92 & 2.11 \\
$2^{*}$ co(REFE) & 33782218.3 & 7.18 \\
$2^{*}$ co(COFE) & 33384991 & 7.10 \\
Total & 470014857 & 100.0 \\
\hline
\end{tabular}

As shown in Table 6, variances in seed, Irrigation, chemical fertilizer, compost, and hired labor costs are high across in Sylhet region. The highest $28.5 \%$ of inequality of gross cost for potato production was explained by the inequality of seed cost, while $17.52 \%$ inequality of gross cost was explained by inequality of hired labor (Figure 9). These costs were the main factors inducing the income differences in potato production. This finding indicates the importance of farming knowledge and easy input access to potato cultivation.

From Table 6 and Figure 9, we found that some costs are the responsible for the total cost disparity; simultaneously it is important to determine the factor causing the net income differences in potato production. The next section we checked the decomposed variance of gross income and gross cost that are presents in Table 7.

Table 7 shows the decomposed variance of gross income and gross cost, where gross income is the main factor in net income difference, which indicates even though farmers in the same region cultivated potato, their gross incomes is dissimilar. These gross income differences mainly induce the net income disparities for potato production in Sylhet region (Figure 10). Additionally, gross cost contributes to the total net income disparity of potato production.

\section{Conclusions}

Regardless of nomenclature, potato has become an important crop to the farmers of Bangladesh for its quick economic return and different purposes of use. It has a wider range of scope and possibilities of reducing food insecurity and poverty alleviation among the crop producers in Bangladesh. A remarkable 


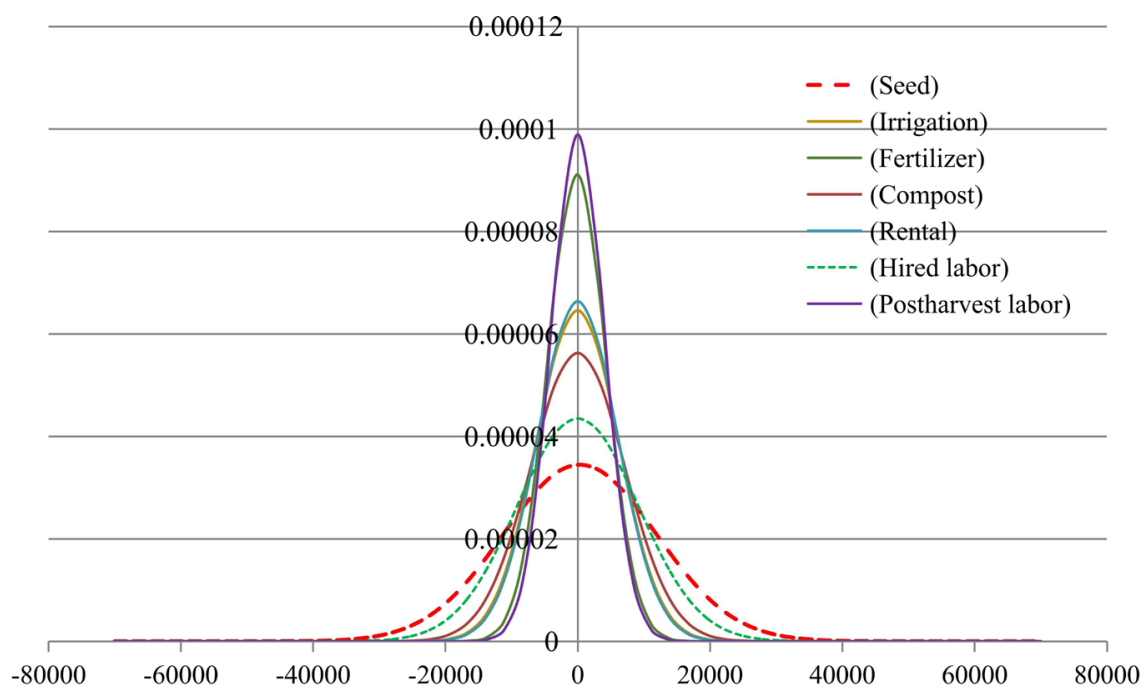

Figure 9. Probability densities for potato production cost.

Table 7. Net income disparity of potato production.

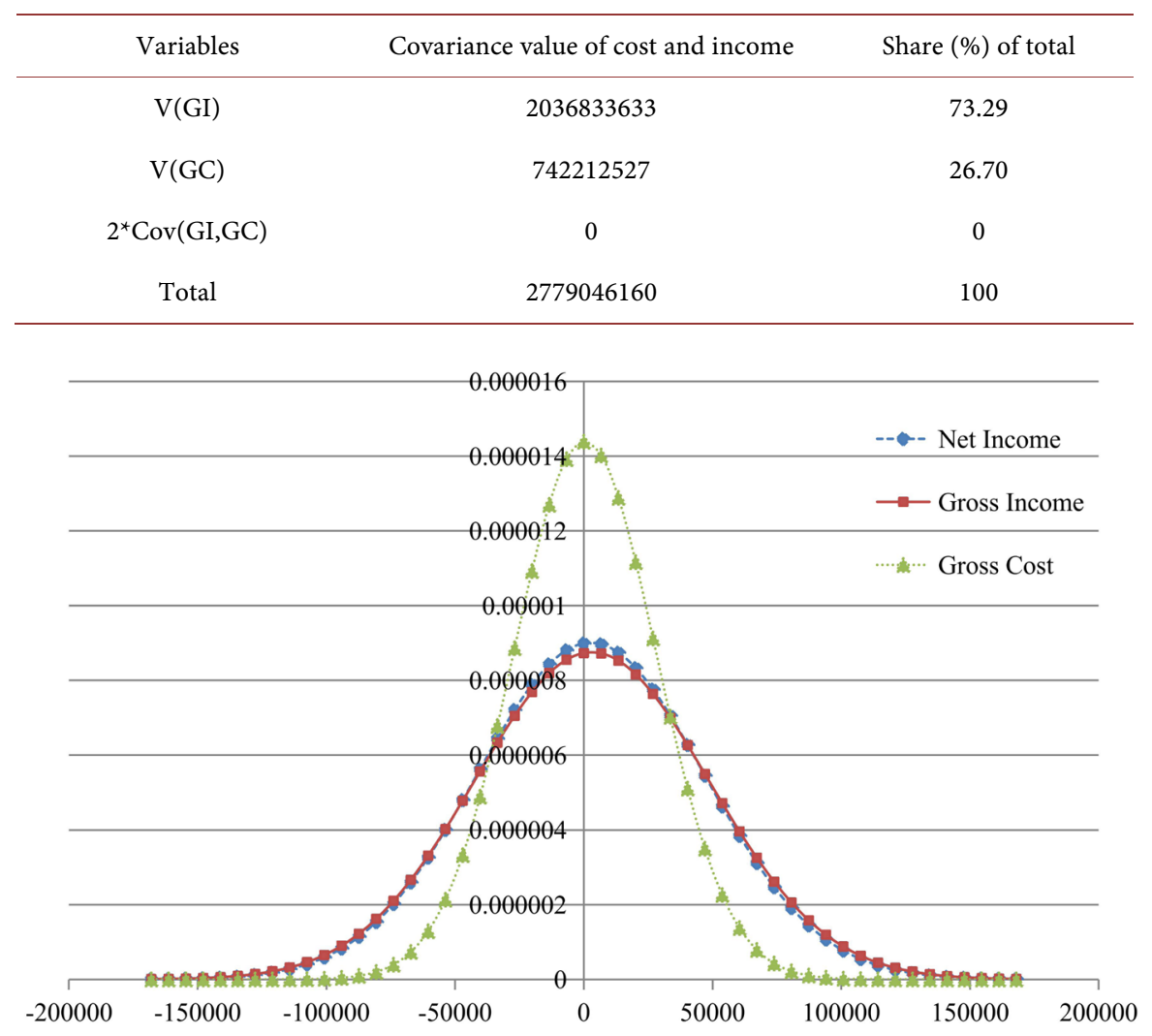

Figure 10. Probability densities of net income for potato production.

number of rural small farmers in Sylhet region of Bangladesh have been cultivating potato and it has turned into their prime source of income instead of growing rice. This paper assesses the socio-economics conditions and ascertains the level of costs and net income variation for potato production in the northeastern part of Bangladesh. The study reveals that most of the households en- 
gaged in agricultural as well as other income generating activities. In addition to farming, remittance is another significant income source on which rural people depends mostly. Rice is the most cultivated crop in the study area compared to potato, which is drawing attention these days to some farmers marginally. However, the gross income differs among the farmers because of some input costs, particularly for the fertilizer and seed cost but they earn considerable profit from potato cultivation. Hence, it is crucial to offer high quality seeds and other basic inputs by the government with least prices or free of costs. Moreover, this study can have a profound contribution to compare the reasons of cost and income variation as well as probable ways to combat such situation by the policy makers.

This study has attempted to bridge the gap between academic research and professional practices in the context of potato crop production in Bangladesh. Statistical power of this analysis may be low due to the small sample size. Thus, future research should attempt to confirm the potato production and its prospects in Sylhet region of Bangladesh and strengthen the results using a larger sample.

\section{Funding}

This research did not receive any external funding.

\section{Conflicts of Interest}

The authors declare that they have no conflict of interest.

\section{References}

[1] CIP (2019) International Potato Center, CIP Headquarters Avenida La Molina 1895, La Molina Apartado 1558, Lima 12, Peru. https://cipotato.org/crops/potato/potato-facts-and-figures

[2] Singh, D.K. and Raigond, P. (2014) Potatoes: A Complete Food. Agropedia, ICAR, NAIP. http://agropedia.iitk.ac.in/content/potatoes-complete-food

[3] Bangladesh Bureau of Statistics (2011) Yearbook of Agricultural Statistics of Bangladesh. Statistics Division, Ministry of Planning, Government of the People's Republic of Bangladesh, Dhaka.

[4] Bangladesh Bureau of Statistics (2014) Yearbook of Agricultural Statistics of Bangladesh. Statistics Division, Ministry of Planning, Government of the People's Republic of Bangladesh, Dhaka.

[5] Bangladesh Bureau of Statistics (2015) Yearbook of Agricultural Statistics of Bangladesh. Statistics Division, Ministry of Planning, Government of the People's Republic of Bangladesh, Dhaka.

[6] Banglapedia (2003) National Encyclopedia of Bangladesh. Revised Edition, Asiatic Society of Bangladesh, Dhaka.

[7] Mandal, R. and Bezbaruah, M.P. (2013) Diversification of Cropping Pattern: Its Determinants and Role in Flood Affected Agriculture of Assam Plains. Indian Journal of Agricultural Economics, 68, 169-181.

[8] Muttaleb, M.A., Shahidullah, S.M., Nasim and Saha, A. (2017) Cropping Systems 
and Land Use in Sylhet Region. Bangladesh Rice Journal, 21, 273-288. https://doi.org/10.3329/brj.v21i2.38211

[9] Azimuddin, M., Alam, Q.M. and Baset, M.A. (2009) Potato for Food Security in Bangladesh. International Journal of Sustainable Crop Production, 4, 94-99.

[10] Chowdhury, M.D. and Chowdhury, A.H. (2015) Problems and Prospects of Potato Cultivation in Bangladesh. Asian Business Review, 5, 28-32. https://doi.org/10.18034/abr.v5i1.49

[11] Hossain, M.A. and Miah, M.A.M. (2010) Post-Harvest Losses and Technical Efficiency of Potato Storage Systems in Bangladesh. Technical Report Submitted to FAO Bangladesh. http://www.fao.org/inpho/content/conpend/text

[12] Food and Agriculture Organization FAO-STAT (2013) Food and Agriculture Organization (FAO), Statistical Database.

[13] Haque, M.M., Tabassum, N., Kabir, N.M.E, Akter, S. and Saha, M. (2015) Study on Profitability Using Modern Inputs against Traditional for Potato Production at Different Agro-Ecological Zones of Bangladesh. Journal of Environmental Science and Natural Resources, 8, 83-87. https://doi.org/10.3329/jesnr.v8i2.26871

[14] Hossain, M.A., Hasan, M.K. and Naher, Q. (2008) Assessment of Technical Efficiency of Potato Producers in Some Selected Areas of Bangladesh. Journal of Agriculture and Rural Development, 6, 113-118. https://doi.org/10.3329/jard.v6i1.1665

[15] Mukul, A.Z.A., Rayhan, S.J. and Hassan, M.M. (2013) Farmer's Profitability of Potato Cultivation at Rangpur District: The Socio-Economic Context of Bangladesh. International Journal of Economics, Finance and Management Sciences, 1, 136-144.

[16] Begum, M.M., Saha, J.K., Rahman, M.A. and Ahmed, M.R. (2017) An Economic Study of Potato Production in Selected Areas of Sylhet District. Journal of the Sylhet Agricultural University, 4, 129-136.

[17] Uddin, M.A., Yasmin, S., Rahman, M.L., Hossain, S.M.B. and Choudhury, R.U. (2010) Challenges of Potato Cultivation in Bangladesh and Developing Digital Databases of Potato. Bangladesh Journal of Agricultural Research, 35, 453-463. https://doi.org/10.3329/bjar.v35i3.6452

[18] FAO (Food and Agriculture Organization) (1988) Land Resources of Bangladesh for Agricultural Development (Report 2: Agro-Ecological Regions of Bangladesh). Rome.

[19] Bangladesh Bureau of Statistics (2018) Yearbook of Agricultural Statistics of Bangladesh. Statistics Division, Ministry of Planning, Government of the People's Republic of Bangladesh, Dhaka.

[20] IFPRI (2013) Agriculture and Adaptation in Bangladesh, Current and Projected Impacts of Climate Change. Discussion Paper 01281, International Food Policy Research Institute, Washington DC.

[21] BER (2017) Bangladesh Economic Review. Government of the People's Republic of Bangladesh, Ministry of Finance, Dhaka.

[22] Todaro, M.P. and Smith, S.C. (2011) Economic Development. Eleventh Edition, Pearson Education Limited, Harlow. 